\title{
International Energy Law Review
}

2012

\section{Production sharing agreements and licences: a distinction without a difference?}

\author{
Chukwuma Samuel Adesina Okoli
}

\author{
Subject: Energy
}

Keywords: Gas licences; Oil and gas production; Petroleum licences; Production sharing contracts

\section{*I.E.L.R. 282 I. Introduction}

States with oil and gas resources develop mechanisms for enjoying their natural resources. The well-known mechanisms are usually licences, production sharing agreements (PSAs) and service contracts. Some states may either use one of such mechanisms exclusively $;{ }^{1}$ or deploy them as hybrids or alternatives. ${ }^{\text {? }}$

The first part of this article defines licences and PSAs, and the rationale for employing each of these mechanisms. The second part of this article deals with what appear to be material reasons why states prefer using licences or PSAs exclusively, or deploying both of them as alternatives. The third part of this article contains the conclusion.

Although various states each have individual special features in using licences or PSAs (which is beyond the scope of this work), this article briefly attempts to reflect an underlying consistency in identifying the material reasons why most states prefer using licences or PSAs exclusively, or deploying both devices as alternatives.

It should also be kept in mind that the state is always faced with the dilemma of ensuring it generates as much revenue as it can from its oil and gas resources; but ensuring that investors are not chased away by the mechanisms it deploys to enjoy its oil and gas resources-which makes the choice between a licence or PSA very material.

Furthermore, states which use licences and PSAs as alternatives create more room for investment, competition and absorption of large, medium and small scale industries. ${ }^{-}$It also gives room for the investor to choose between a licence and PSA. ${ }^{4}$

In this article, the writer holds the view that although licences and PSAs share and achieve the same purpose $^{5}$ of generating revenue for states; there appear to be material reasons why most states prefer using licences or PSAs exclusively, or deploy both devices as alternatives.

\section{Definition and rationale for using licences or PSAs}

A licence is a permit granted by the state to an investor to explore, develop and produce oil and gas at its own risk and cost for a specified period of time. In return, the investor pays taxes or royalties to the state. ${ }^{6}$

Licences are usually utilised in provinces which are relatively depleted. ${ }^{7}$ From the perspective of the state, it is concerned with ensuring that trusted investors with relevant financial and technical expertise use its depleted petroleum resources for the best use of the state concerned.. Thus, licences are usually granted after a tender or bidding process.

A PSA is a contract ${ }^{9}$ between a state ${ }^{10}$ and an investor, in which the investor at his own cost and risk agrees to explore, develop and produce petroleum resources for the state for a specified period of time. In return, the state rewards the investor with a share of the petroleum resources. The investor is usually first given "cost oil" to cater for the cost of the petroleum exploration; and later, *I.E.L.R. 283 "compensation oil" (or "production or profit oil") to cater for petroleum production, which the investor sells at the international market. ${ }^{11}$

PSAs are usually deployed in states where the field is new or just discovered, relatively unexplored, undeveloped or has less appealing prospects. ${ }^{12}$ The state uses PSA as an attractive mechanism to 
get an oil company with technical, material infrastructure, labour and capital to explore and develop its oil and gas resources.

From the above it can be inferred that states utilising PSAs or licences are all concerned with ensuring the investor has the relevant expertise in a bid to generate revenue for the state. $\frac{13}{}$

However, an important difference ${ }^{\frac{14}{4}}$ may be spotted from the definition of a licence and PSA. In PSAs, the state generates its revenue by placing premium on sharing the oil and gas production with the investor: $; 5$ while in licences, the state usually places a very high premium on taxation or royalties. ${ }^{16}$

Other material differences are discussed hereunder.

\section{i. Developing versus developed countries}

It has been observed, that most developing countries are inclined to use PSAs, while most developed countries prefer licences..$^{17}$

First, developing countries, with a sad history of colonialism are quick to make a statement on the sovereignty over its natural resources and are unwilling to grant an investor ownership over such resource. ${ }^{18}$ In the same vein, it is another way the state tells its citizens that its petroleum resources are being used for its benefit. ${ }^{19}$

Secondly, developing countries usually do not have the technological and financial capability to embark on exploration of its natural resources and needs the assistance of an investor that has such capabilities.

From the perspective of most developed countries, they are usually concerned with ensuring that their depleted petroleum province are best utilised by trusted investors. Secondly, most developed countries are usually more concerned with (among others) efficient tax and auditing systems-licences are proven to play a better role here. ${ }^{20}$

\section{ii. Flexibility}

PSAs appear to create more room for flexibility than licences. PSAs appear to be more participatory than licences, which are based on resource ownership. ${ }^{21}$ Secondly, the investor is given more room to go about his exploration of natural resources and the rules on the bidding process, taxation, imports, exports, requirement as to the use of land and type of labour used may be relaxed..$^{22}$ Thirdly, there is room for negotiation by the investor and the state regarding the terms of the contract. ${ }^{23}$ Fourthly, the investor is in a better position to use his petroleum field as securitisation, e.g for a bank loan or mortgage. ${ }^{24}$ Lastly, the investor is allowed to book reserves represented by share of its oil on its balance sheet. $\frac{25}{}$

On the other hand, licences appear to give the investor an option of "take it or leave it". ${ }^{26}$ The investor usually has to be granted a licence after a successful bidding process. ${ }^{27}$ Secondly, the rules on taxation, use of labour, and the terms of using the oil field appear to be strict. $\stackrel{28}{ }$ Thirdly, the investor is in little or no position to use his petroleum field for securitisation. $\frac{29}{9}$ This may scare the investor.

\section{iii. Duration of exploration}

PSAs appear to give longer duration (than licences do) for exploration and exploitation of oil and gas resources. ${ }^{30}$ From the perspective of most states using PSAs, it is an attractive means to get the investor into its domain, with *I.E.L.R. 284 lucrative prospects of the investor having a long term to enjoy its investment. ${ }^{31}$ From the perspective of most states using licences, they give the investor a relatively short period of time to see if the investor is able to utilise its near depleted petroleum field to best use. ${ }^{32}$ If the state considers the investor is unable utilise the petroleum field within that relatively short period of time, the investor will likely lose its license to the petroleum field.

\section{iv. Local content}

Most states in theory utilise PSAs as a vehicle to create jobs for its indigenes. $\frac{33}{\underline{3}}$ Thus, investors are mandated to utilise local infrastructure and human capital within the state and to transfer technology to local professionals. ${ }^{34}$ On the other hand, most states that utilise licences in theory appear to make 
a statement of non-discrimination among investors in utilising infrastructure and human capital. $\frac{35}{3}$

\section{v. Regulation}

Sates utilise licences as a better mechanism to enforce regulatory and administrative measures on the investor while exploiting its natural resources. $\frac{36}{}$ Thus, states that utilise licences are known to develop stringent measures to ensure the oil company does not violate (among others) tax and auditing requirements. ${ }^{37}$ The danger is that the state may scare investors who may find the regulatory measures developed by the state's authorities to be conflicting ${ }^{38}$ or find the standard too high to comply with. ${ }^{39}$

However, states usually deploy PSAs as an alternative mechanism to relax strict rules (among others) on the bidding process, tax, auditing requirements, import, exports and labour requirements in order to attract investors to its undeveloped oil and gas field. ${ }^{40}$

\section{vi. Investment risk}

Although, in both PSAs and licences, the investor embarks at his own cost and risk, there appear to be certain differences that apply to both of them.

First, most states that use PSA (unlike licences ${ }^{41}$ ) does not confer ownership title on the investor. The danger is that if the state acquires the developed petroleum field(s) from an investor, all its assets on the field reverts to the state thereby depriving the investor of its legitimate expectation. ${ }^{42}$ Thus, investors should be wary of investing in the state if they do not have sufficient legal protection in the form of a stabilisation and renegotiation clause. $\frac{43}{}$

Secondly, PSAs in theory ${ }^{44}$ appear to create legal protection for the investor in the form of a stabilisation or renegotiation clause in order to create commercial certainty and security for the investor concerned. ${ }^{45}$ Most states that use licences in theory do not usually have stabilisation clauses and thus if the state changes any of its laws or regulation, the investor may be in a precarious position. $\underline{46}$

\section{vii. Competition}

States that utilise licences appear to create more room for competition among investors than states that utilise PSAs. First, a bidding or tender process is usually a requirement in awarding a licence in order to ensure the most trusted investors with technical and financial expertise are awarded the almost depleted petroleum field to explore. ${ }^{47}$ States that use PSAs are more inclined to relax the rules on the bidding process since the petroleum field is relatively new or undeveloped. ${ }^{48}$

Similarly, unlike in PSAs, the short and prescribed time table given to investors in licensing regimes to explore, develop and produce oil and gas, creates competition among investors to perform effectively or risk losing their acreage. ${ }^{*}$.E.L.R. $285^{49}$

\section{Conclusion}

This article takes the position that although states utilise both licences and PSAs to achieve the same purpose of generating revenue from the oil and gas resources of the state concerned; there appear to be material reasons why most states prefer utilising licences or PSAs as alternatives, or utilise one of them exclusively.

\section{Chukwuma Samuel Adesina Okoli}

Barrister and Solicitor of the Supreme Court of Nigeria

I.E.L.R. 2012, 8, 282-285 
expressed in this article. Comments sent to the author at chuksamde@yahoo.com are welcome.

1. e.g. United Kingdom (s.3(1) of the Petroleum Act 1998), Norway, Canada and Australia. See also G. Gordon "Petroleum Licensing" in G. Gordon, J. Paterson and E. Usenmez (eds), Oil and Gas Law-Current Practice and Emerging Trends (Dundee University Press, 2011), [4.2].

2. $\quad$ e.g. Russia-D. Doreh, "Oil, Law and Politics in Russia" [2005] I.E.L.T.R. 207; K. Svendsen, "The Russian Regime for Subsoil Use, Energy and Environmental Policy in the High North" [2008] Envtl. L. Rep. 288, 290; Uzbekistan-D. Bayzakova, "Current Challenges, Future Prospects: Legal Governance of the Petroleum Industry in Uzbekistan" [2011] I.E.L.R. 238, 239; Ukraine-B.C. Toms, T. Yaremko, I. Voyteskhovska and A. Kvederis, "Ukrainian Law on the Exploration and Production of Oil and Gas and other Natural Resources" [2011] I.E.L.R. 116, 121; see also L. Moller, "The Governance of Oil and Gas Operations in Hostile but Attractive Regions: West Africa" [2010] I.E.L.R. 110, $113-114$.

3. A. Konoplyanik, "The Fight against PSAs in Russia: who is to benefit and why not the State?"[2003] I.E.L.T.R. 277, 279.

4. $\quad$ Konoplyanik, "The Fight against PSAs in Russia: who is to benefit and why not the State?" [2003] I.E.L.T.R. $277,279$.

5. See also I. Musselli and S. Zairilli, "Oil and Gas Services: Market Liberalisation and the On-going GATS Negotiations" [2005] J.I.E.L. 551, 557; FN. Prowse, P. Rocher, E. Walshe, and S. Petit, "NOC and IOCs: Resolving Tensions" [2009] I.E.L.R. 285; M.R. de Oliveria, "The Overhaul of the Brazilian Oil and Gas Regime: Does the Adoption of a Production Sharing Agreement Bring any Advantage Over the Modern Concession System?" [2010] 4 O.G.E.L. 1, 12; Miguel Soares Branco, "Legal Blessing or Curse for Developing Countries" [2012] I.E.L.R. 147-150.

6. $\quad$ Section 3(3) of the Petroleum Act 1998; Konoplyanik (fn.3) 279; Doreh (fn.2) 556; Musselli and Zairilli, (fn.5) 556; C. Clement-Davies, "Iraqi's Oil and Gas Framework" [2009] I.E.L.R. 138; Energy Law Group, "Underground Gas Storage in Europe: A Legal Overview" [2010] I.E.L.R. 228, 229; Gordon (fn.1), [4.28]-[4.30].

7. $\quad$ M. Hammerson, Upstream Oil and Gas (London: Globe Business Publishing Ltd, 2011), 5.12.

8. $\quad$ Gordon (fn.1), [4.35]-[4.69].

9. The contract may be given legislative backing by local statute or international treaty.

10. It may use a National Oil Company (NOC) to contract on its behalf.

11. B.C. Toms, "Ukrainian Law on Oil and Gas Exploration and Production" [2003] I.E.L.T.R. 21, 23; Energy Law Group (fn.6) 229; Svendsen (fn.2) 291; Clement-Davies (fn.6) 14; Bayzakova (fn.2) 40; D. Taz, "Petroleum Development in the Kurdistan Region of Iraq: A Struggle over Competency" [2011] I.E.L.R. 225; Toms et al. (fn.2), 121-123.

12. N.L. Khodadad, "Libya Unveils Terms for Foreign Investors" [2005] I.E.L.T.R. 1; Clement-Davies (fn.6) 146; Toms et al. (fn.2), 121; Bayzakova (fn.2) 240.

13. Excalibur Ventures LLC v Texas Keystore Inc [2011] EWHC 1624 [20]; Toms (fn.11) 23; Clement-Davies (fn.6) 144; D. Cheroun and P. Ehrhart, "Energy and Infrastructure" [2011] 1 I.B.J.L. 116, 129; Toms et al., (fn.2), 121-122; Svendsen (fn.2) 292.

14. Perhaps the most important.

15. Konoplyanik (fn.3) 279-280; Doreh (fn.2) 207. States using PSAs in the alternative usually use rental charges or special taxes, which in most situations is not as effective as the tax or royalty system in licensing regimes. In this regard, see R. Worall and S. Diyachenko, "Recent Amendments to the Legislation on Production Sharing Agreements in Russia, Ukraine and Azerbaijan" [2000] 6 I.E.L.R. 138; Toms (fn.7) 21, 25-26; Svendsen (fn.2) 291; Oliveria (fn.5) 58.

16. Section 3(3) of the Petroleum Act 1998 (UK); Worall \& Diyachenko (fn.15) 137-138; Toms (fn.11) 21, 25-26; Oliveria (fn.5) 58.

17. Oliveria (fn.5) 26-27, 46-47; Svendsen (fn.2) 291; Miguel Soares Branco, "Legal Blessing or Curse for Developing Countries" (fn.5) 147-148.

18. Clement-Davies (fn.6) 146; Oliveria (fn.5) 26-27, 46-47; Moller (fn.2) 113-115; Bayzakova (fn.2) 239; Hammerson (fn.7), [1.12].

19. Hammerson (fn.7), [1.12].

20. Toms (fn.11) 23-24; Svendsen (fn.2) 292; Cheroun and Ehrhart (fn.13) 129.

21. Worall and Diyachenko (fn.15) 138; Toms (fn.7) 22; Konoplyanik (fn.3) 277; Clement-Davies (fn.6) 145-146; Bayzakova (fn.2) 239; contra Prowse FN. et al (fn.5) 285; Oliveria (fn.5) 59.

22. Worall and Diyachenko (fn.15) 138; Toms (fn.11) 25-27; Toms et al. (fn.2), 124-125.

23. Svendsen (fn.2) 292; Moller (fn.2) 114; Bayzakova (fn.2) 242. 
24. Svendsen (fn.2) 292; Toms et al. (fn.2), 124-125. The problem with this is that where no oil discovery is made, the state's economy is to lose, since the investor may find difficulty in paying the bank and the security of the petroleum field is as well useless.

25. Clement-Davies (fn.2) 145.

26. Konoplyanik (fn.3) 277; Svendsen (fn.2) 292.

27. Oliveria (fn.5) 31; G. Gordon, [4.31]-[4.34].

28. Toms (fn.11) 23; Svendsen (fn.2) 292; D. Cheroun and P. Ehrhart (fn.13) 129.

29. Svendsen (fn.2) 292; Hammerson (fn.7), [1.15].

30. Toms (fn.11) 26-27; Konoplyanik (fn.3) 277; Toms et al. (fn.2), 124-125; contra Oliveria (fn.5) 77.

31. Konoplyanik (fn.3) 277.

32. Gordon, (fn.1), [4.35]-[4.69].

33. Toms (fn.11) 25; Worall and Diyachenko (fn.15) 138; Konoplyanik (fn.3) 286; Bayzakova (fn.2) 242-243; J.N.E. Nwaokoro, "Nigeria's National Content Bill: the Hype, the Hope and the Reality" [2011] J.A.L. 128, 152-154; contra Prowse et al. (fn.5) 285; Moller (fn.2) 115; Oliveria (fn.5) 17.

34. Toms (fn.11) 25; Worall and Diyachenko (fn.15) 138; Konoplyanik (fn.3) 286; Bayzakova (fn.2) 242-243; Nwaokoro (fn.33) 152-154; contra Prowse et al. (fn.5) 285; Moller (fn.2) 115; Oliveria (fn.5) 17.

35. Energy Law Group (fn.6) 238; Gordon, (fn.1), [4.32]-[4.33]; contra Oliveria (fn.5) 17.

36. Toms (fn.11) 23; Svendsen (fn.2) 292; Cheroun and Ehrhart (fn.13) 129; contra Oliveria (fn.5) 77.

37. Toms (fn.11) 23; Svendsen (fn.2) 292; Cheroun and Ehrhart (fn.13) 129; contra Oliveria (fn.5) 77; Gordon, (fn.10), [4.24]-[4.27].

38. Toms (fn.11) 27; Toms et al. (fn.2), 124-125.

39. Hammerson (fn.7), [5.16].

40. Konoplyanik (fn.3) 277-279, 285-286; Toms (fn.11) 27; Toms et al. (fn.2), 124-125.

41. Contra Hammerson (fn.7), [5.15]-[5.16].

42. Parkerings v Lithuania ICSID, Case No.ARB/05/8 decided September 11, 2007 at [327]-[338]; Total v Argentina 2010 ICSID, Case No.ARB/04/1, decided December 27, 2010 at [115]-[123]; Impreglio v Argentina, ICSID, Case No.ARB/07/17, decided June 21, 2011 at [290].

43. Parkerings v Lithuania ICSID, Case No.ARB/05/8 decided September 11, 2007 at [327]-[338]; Total v Argentina 2010 ICSID, Case No.ARB/04/1, decided December 27, 2010 at [115]-[123]; Impreglio v Argentina, ICSID, Case No.ARB/07/17, decided June 21, 2011 at [290].

44. Ironically, PSA regimes appear to have more cases of expropriation than licences. See also E. Khali, "A Selection of Views on the Expropriation of Interests in the Mineral and Petroleum Extraction Industries" [2008] 3 I.E.L.R. 79, 93-96.

45. See also Toms (fn.7) 27; Svendsen (fn.2) 292; Bayzakova (fn.2) 239-240; Toms et al. (fn.2), 124-125; Khali (fn.46) 93-96; T. Oyewunmi, "Stabilisation and Renegotiation Clauses in Production Sharing Contracts: Examining the Problems and Key issues" [2011] 4 O.G.E.L. 1. However, the investor may be unable to benefit from a change in the law that suits him.

46. However, the investor may be in a position to benefit in a change of the law that suits him.

47. See also Gordon, (fn.1), [4.31]-[4.34].

48. See also Toms (fn.7) 25.

49. Gordon (fn.1), [4.35]-[4.69]. 